\title{
Dryland pasture yields and botanical composition over 5 years under sheep grazing in Canterbury
}

\author{
A. MILLS, M.C. SMITH, R.J. LUCAS and D.J. MOOT \\ Agriculture and Life Sciences Division, Lincoln University, Lincoln 7647, Lincoln \\ millsa@lincoln.ac.nz
}

\begin{abstract}
Annual dry matter (DM) production and botanical composition of six dryland pasture combinations, grown under sheep grazing at Lincoln University for 5 years, are presented. In 4 years, lucerne produced the highest DM yields (13.1-18.5 t/ha/yr) through higher daily growth rates, compared with grass based pastures, particularly during periods of water stress in summer and autumn. Of the grass based pastures, cocksfoot sown with subterranean clover produced yields of 9.9-12.9 $\mathrm{t}$ $\mathrm{DM} / \mathrm{ha} / \mathrm{yr}$ which were greater than, or similar to, all other pastures (8.0-12.9 t DM/ha/yr). Cocksfoot established with white clover produced $>9.7 \mathrm{t} \mathrm{DM} / \mathrm{ha} / \mathrm{yr}$ in years with wetter than average summers. Over the 5 years the contribution of perennial ryegrass to total DM yield declined by $\sim 0.7 \mathrm{t} / \mathrm{ha} / \mathrm{yr}$, from $70 \%$ in Year 1 , to $44 \%$ in Year 5. It was replaced by unsown dicotyledonous weeds and grasses which increased from $4 \%$ in Year 1 to $24 \%$ by Year 5 . Overall results show a dryland pastoral system that includes both lucerne and cocksfoot with subterranean clover pastures is likely to produce more feed in dry years than perennial ryegrass/white clover pastures. The inclusion of white clover with cocksfoot and subterranean clover may allow utilisation of variable and unpredictable rainfall in moist summers.
\end{abstract}

Keywords: Dactylis glomerata, dry matter yield, Lolium perenne, temperature, thermal time, Trifolium ambiguum, Trifolium michelianum, Trifolium subterraneum, Trifolium repens.

\section{Introduction}

Dryland pastoral environments in New Zealand are usually subjected to periods of summer/autumn moisture stress. This reduces production, persistence and recovery of traditional perennial ryegrass/white clover pastures (Woodman et al. 1992; Knowles et al. 2003). In these environments inclusion of lucerne and more drought tolerant grass and legume combinations enhances pasture production (Brown et al. 2006). Cocksfoot has been shown to tolerate, recover and persist in drought prone environments (Norris 1982). However, it is often nitrogen (N) deficient (Mills et al. 2006) because of its competitive advantage in water extraction over companion legumes such as white clover (Lee \& Cho 1985). Over time, this limits production (Mills et al. 2006) and reduces transfer of biologically fixed $\mathrm{N}$ to the grass which may then also be rejected by livestock (Edwards et al. 1993).

The current study compared DM production and botanical composition of cocksfoot (CF) pastures, sown with annual and perennial legumes, with a perennial ryegrass/white clover pasture and a lucerne monoculture as controls. Annual subterranean (Sub; Trifolium subterraneum) and balansa (Bal; T. michelianum) clovers, complete their lifecycle in late spring so do not directly compete with cocksfoot for scarce moisture in summer. White clover (Wc; T. repens) was included because it is a component of most cocksfoot pasture mixes and Caucasian clover (Cc; T. ambiguum) has a taproot and rhizomes that may allow it to compete with cocksfoot in summer (Black \& Lucas 2000). This paper summarises 5 years of results from the 'MaxClover' Grazing Experiment at Lincoln University, Canterbury.

\section{Materials and Methods}

On 18/2/2002, a randomised complete block (RCB) experiment was established at Lincoln University on a Templeton silt loam soil of 0.85-1.45 m depth above alluvial gravels. The six pastures were cocksfoot established with subterranean ( $\mathrm{CF} / \mathrm{Sub})$; balansa $(\mathrm{CF} /$ $\mathrm{Bal})$; white $(\mathrm{CF} / \mathrm{Wc})$ or Caucasian $(\mathrm{CF} / \mathrm{Cc})$ clover in four replicates of $22 \times 23 \mathrm{~m}$ plots. A perennial ryegrass/ white clover $(\mathrm{RG} / \mathrm{Wc})$ control pasture and a lucerne (Luc) monoculture were also included. An additional two replicates were established in an adjacent paddock in autumn 2003. Full experimental details, which include sowing rate, cultivar, grazing management and measurements have been published previously (Brown et al. 2006). Grazing management aimed to provide best management practices for each pasture combination for five growth seasons (2002-2007). Annual and seasonal liveweight production $(\mathrm{kg} / \mathrm{ha})$ for Years 2-6 are presented in Mills et al. (2008).

\section{Environmental conditions}

Long-term mean (LTM) annual air temperature is $11.4^{\circ} \mathrm{C}$ (Fig. 1a) and increases from $5.5^{\circ} \mathrm{C}$ in July to $16.6^{\circ} \mathrm{C}$ in January. The LTM annual (Jul-Jun) rainfall is $635 \mathrm{~mm} /$ yr (1975-2001) but ranged from $460(2002 / 03)$ to 645 $\mathrm{mm} / \mathrm{yr}$ in 2006/07 during the experimental period (Fig. 1b). The first measurement year (Table 1) ran from $4 / 9 /$ 2002 to $30 / 6 / 2003$ (299 d) during which time rainfall totalled $415 \mathrm{~mm}$. The LTM monthly rainfall is $42-67$ 
Figure 1 Monthly (a) mean air temperature and (b) rainfall at Lincoln, Canterbury. Total annual rainfall was 415 $\mathrm{mm}$ in 2002/03, $494 \mathrm{~mm}$ in 2003/04, $635 \mathrm{~mm}$ in 2004/05, $601 \mathrm{~mm}$ in 2005/06, and $643 \mathrm{~mm}$ in 2006/07. Long-term means $(-)$ are for the period 1975-2001. Data from the Broadfields meteorological site located $2 \mathrm{~km}$ north of the experiment site.
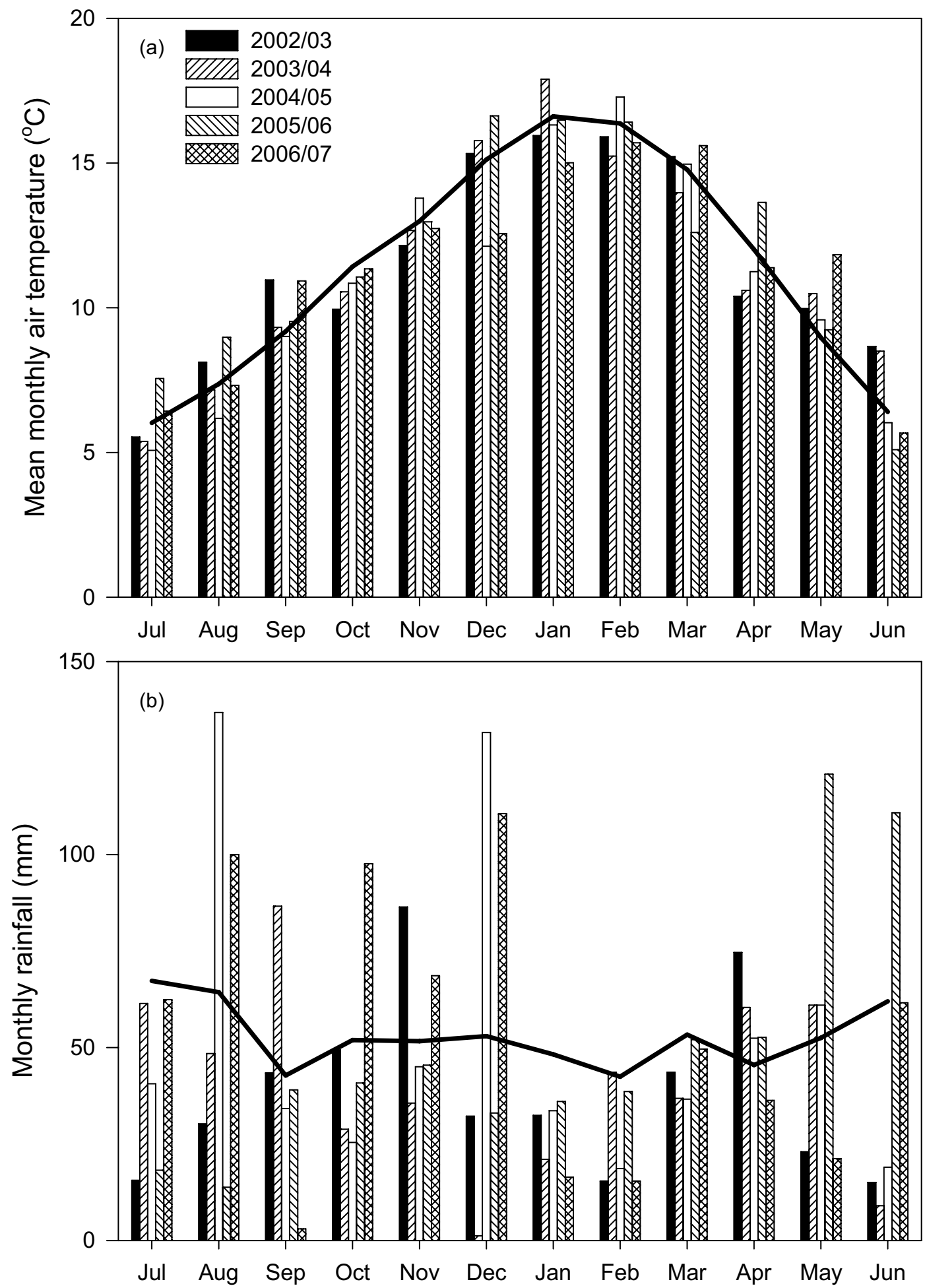
Table 1 Harvest dates and regrowth duration (d) for individual rotations and annual totals (d) for five growth seasons of grass based pastures at the 'MaxClover' Grazing Experiment at Lincoln University, Canterbury, New Zealand.

\begin{tabular}{|c|c|c|c|c|c|c|c|c|c|}
\hline \multicolumn{2}{|c|}{$\begin{array}{l}2002 / 03 \\
(\text { Year 1) }\end{array}$} & \multicolumn{2}{|c|}{$\begin{array}{l}2003 / 04 \\
\text { (Year 2) }\end{array}$} & \multicolumn{2}{|c|}{$\begin{array}{l}2004 / 05 \\
\text { (Year 3) }\end{array}$} & \multicolumn{2}{|c|}{$\begin{array}{l}2005 / 06 \\
\text { (Year 4) }\end{array}$} & \multicolumn{2}{|c|}{$\begin{array}{l}2006 / 07 \\
\text { (Year 5) }\end{array}$} \\
\hline Date & (d) & Date & (d) & Date & (d) & Date & (d) & Date & (d) \\
\hline $2 / 10$ & 28 & $24 / 07$ & 23 & $30 / 08$ & 61 & $11 / 08$ & 44 & $11 / 07$ & 10 \\
\hline $30 / 10$ & 28 & $27 / 08$ & 34 & $5 / 10$ & 36 & $8 / 09$ & 28 & $7 / 09$ & 58 \\
\hline $21 / 11$ & 22 & $6 / 10$ & 40 & $2 / 11$ & 28 & $12 / 10$ & 34 & $10 / 10$ & 33 \\
\hline $11 / 12$ & 20 & $4 / 11$ & 29 & $30 / 11$ & 28 & $10 / 11$ & 29 & $10 / 11$ & 31 \\
\hline $8 / 01$ & 28 & $11 / 12$ & 37 & $5 / 01$ & 36 & $20 / 12$ & 40 & $11 / 12$ & 31 \\
\hline 20/02 & 43 & $10 / 03$ & 90 & $1 / 02$ & 27 & $31 / 01$ & 42 & $8 / 01$ & 28 \\
\hline $23 / 04$ & 62 & $3 / 05$ & 54 & $28 / 02$ & 27 & $16 / 03$ & 44 & $5 / 02$ & 28 \\
\hline $27 / 05$ & 34 & & & $4 / 04$ & 35 & $10 / 05$ & 55 & $22 / 03$ & 45 \\
\hline \multirow[t]{2}{*}{$30 / 06$} & 34 & & & $11 / 05$ & 37 & $30 / 06$ & 51 & $30 / 04$ & 39 \\
\hline & & & & $27 / 06$ & 47 & & & $26 / 6$ & 57 \\
\hline Annual & 299 & & 364 & & 362 & & 367 & & 360 \\
\hline
\end{tabular}

Figure 2 Total accumulated annual dry matter (DM) production of CF/Sub, CF/Bal, CF/Wc, CF/Cc, RG/Wc and lucerne pastures for five growth seasons (2002-2007). Accumulation for Year 1 began on 4/9/2002. Error bars are SEM for total annual yields for each growth season.

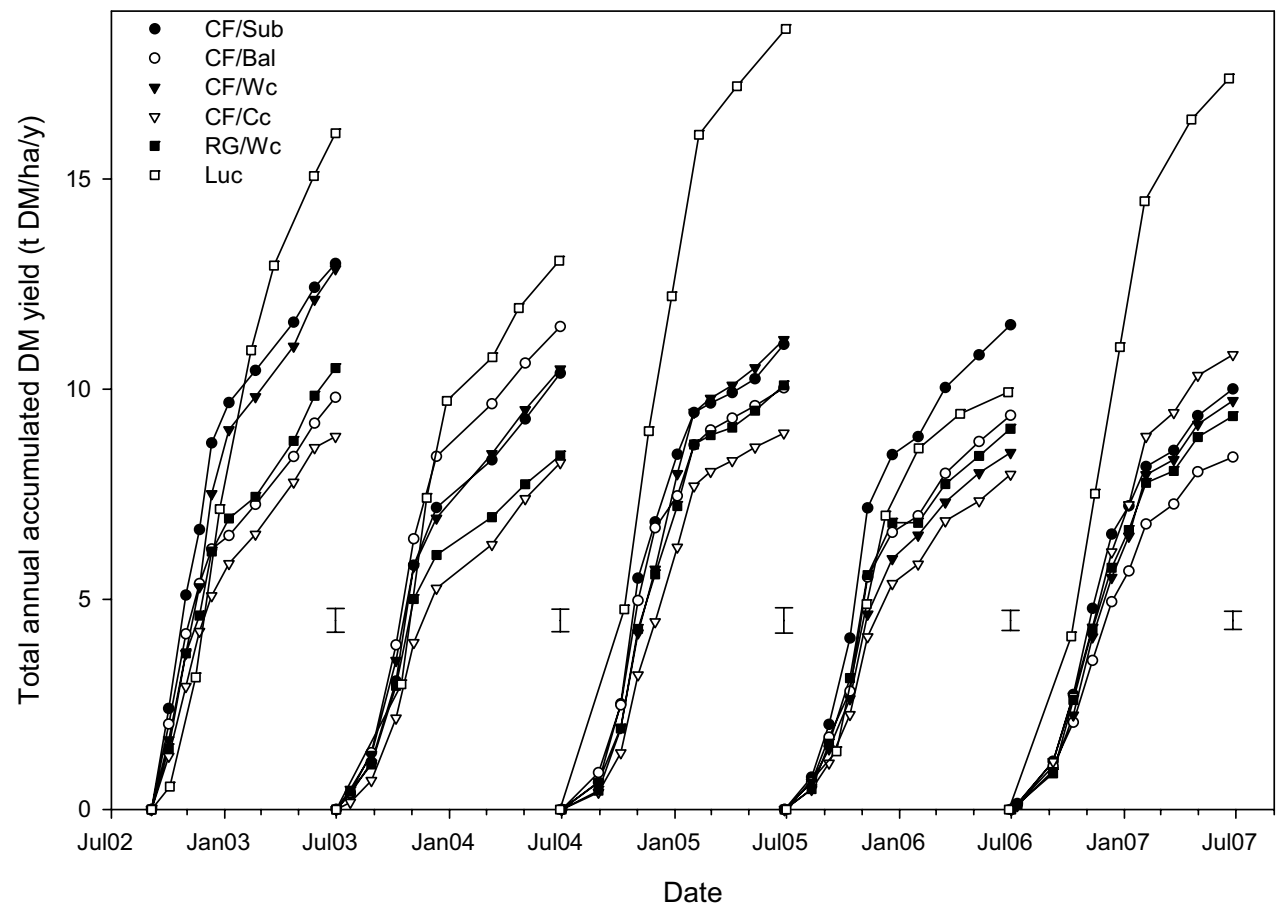

$\mathrm{mm} / \mathrm{month}$ throughout the year and, during the measurement period, ranged from $1 \mathrm{~mm}$ in December 2003 to $>130 \mathrm{~mm}$ in August and December 2004.

\section{Measurements}

Yields and botanical composition of grass based pastures were recorded from exclosure cage harvests. After each harvest, an area $\left(1.0 \mathrm{~m}^{2}\right)$ of the pasture was trimmed to $25-30 \mathrm{~mm}$, which was representative of grazing height across the entire plot area, and the cage repositioned. Areas previously harvested were avoided for $\geq 2$ years. There were $8-10$ regrowth cycles per growth season (Table 1) and 46 regrowth cycles in total. Regrowth duration ranged from $20 \mathrm{~d}$ during periods of rapid growth to a maximum of $90 \mathrm{~d}$ during winter or when dry soil moisture conditions restricted growth.

At harvest, DM production was measured from a 0.2 
Figure 3 Mean daily growth rate $(\mathrm{kg} / \mathrm{ha} / \mathrm{d})$ of dryland CF/Sub, CF/Bal, CF/Wc, CF/Cc, RG/Wc and lucerne pastures for (a) five growth seasons (2002-2007) at Lincoln University, Canterbury and (b) accumulated spring (Jul-Nov) DM production of grass-based pastures against accumulated thermal time above a base temperature for growth of $3^{\circ} \mathrm{C}$. Data points are mean accumulated DM yield from July in each year and mean accumulated thermal time separated by harvests in July, August, September, October and November. Where CF/Sub Yield = 8.3x-901 $\left(R^{2}=0.99\right)$; CF/Bal Yield $=7.3 x-$ $901\left(R^{2}=0.99\right)$; CF/Wc Yield $=6.8 x-901\left(R^{2}=0.99\right), C F / C c$ Yield $=5.7 x-901\left(R^{2}=0.99\right)$ and $R G / W c$ Yield $=7.0 x-901\left(R^{2}=0.99\right)$.

(a)

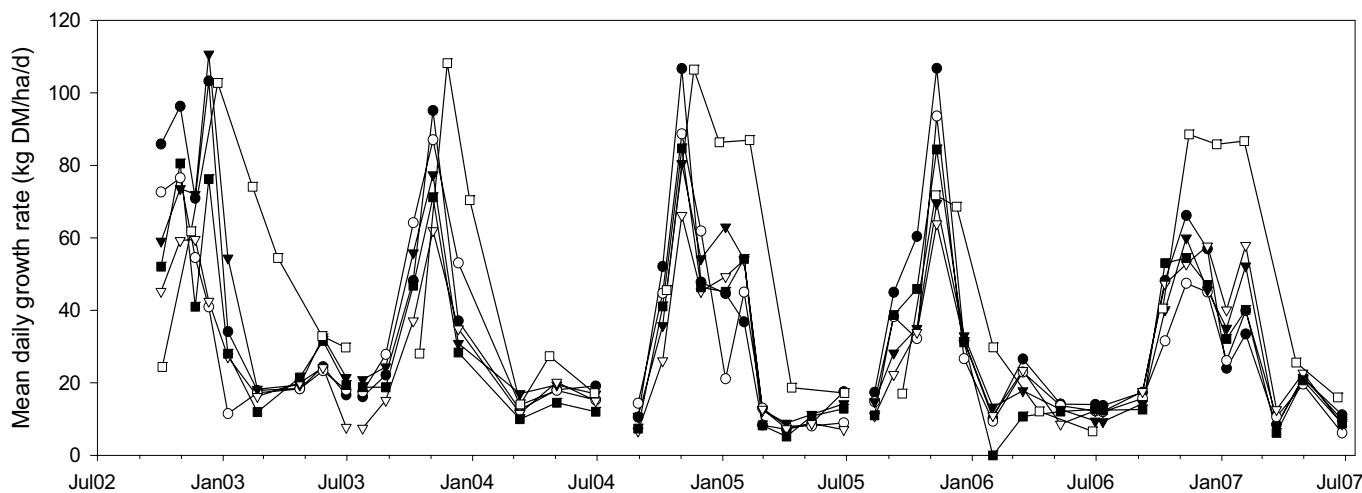

(b)

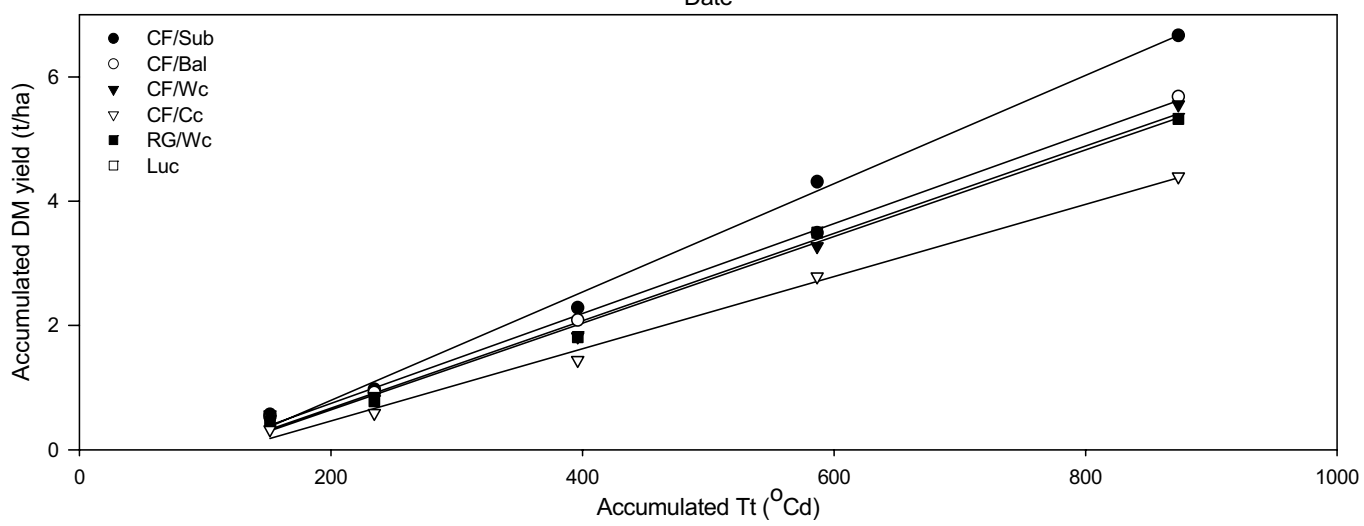

$\mathrm{m}^{2}$ quadrat cut to $25-30 \mathrm{~mm}$ with a set of electric clippers. For grass based pastures, botanical composition was determined from subsamples of $\geq 50 \mathrm{~g}$ freshweight which were sorted into sown grass, sown legume, volunteer white clover, dicotyledonous (dicot.) weed, unsown grass and dead ( $>50 \%$ senesced) material. Lucerne production was measured from $5 \times 0.2$ $\mathrm{m}^{2}$ quadrats/plot cut to $25-30 \mathrm{~mm}$ prior to each grazing. Entire samples were sorted into sown legume, weed (unsown grasses + volunteer white clover + dicot. weed) and dead fractions.

\section{Analysis}

Annual DM production was calculated from the sum of yields from individual regrowth cycles. Data were analysed as a RCB with four (Years 1 and 2) or six (Years 3-5) replicates using a one way analysis of variance in Genstat 10. Means were separated by Fisher's protected LSD at $\alpha=0.05$.

\section{Results}

\section{Total annual accumulated DM production}

Over the five growth seasons, total annual DM yields were between $8.0 \mathrm{t} / \mathrm{ha} / \mathrm{yr}(\mathrm{CF} / \mathrm{Cc}$ pastures in 2005/06) and $18.5 \mathrm{t} / \mathrm{ha} / \mathrm{yr}$ from lucerne in 2004/05 (Fig. 2). Lucerne DM yields in Years 1, 2, 3 and 5 were 13.1-18.5 t/ha/yr which were $14-66 \%$ higher $(\mathrm{P}<0.001)$ than the highest yielding grass based pasture in 4 of the 5 years. In 2005/ $06, \mathrm{CF} / \mathrm{Sub}$ pastures produced $16 \%$ more $(\mathrm{P}<0.001)$ than the $10.0 \mathrm{t} / \mathrm{ha} / \mathrm{yr}$ from lucerne. Annually, the $\mathrm{CF} / \mathrm{Sub}$ pastures produced yields that were greater than, or similar to, $\mathrm{CF} / \mathrm{Wc}$ and $\mathrm{RG} / \mathrm{Wc}$ pastures in all years.

Over the five growth seasons, mean daily growth rates ranged from no growth in $\mathrm{RG} / \mathrm{Wc}$ pastures, for the rotation ending $31 / 1 / 2006$, to a maximum of $111 \mathrm{~kg} \mathrm{DM} / \mathrm{ha} / \mathrm{d}$ by $\mathrm{CF} / \mathrm{Wc}$ in the establishment year (Fig. 3a). With the exception of 2005/06, the yield advantage of lucerne occurred predominantly in the summer/autumn period. In contrast, the highest mean daily growth rates of the 
Figure 4 Annual DM yields ( $\mathrm{t} / \mathrm{ha} / \mathrm{yr}$ ) of the sown grass component of dryland CF/Sub, CF/Bal, CF/Wc, CF/Cc and RG/Wc pastures over five growth seasons at Lincoln University, Canterbury, New Zealand. Error bar is the maximum SEM.

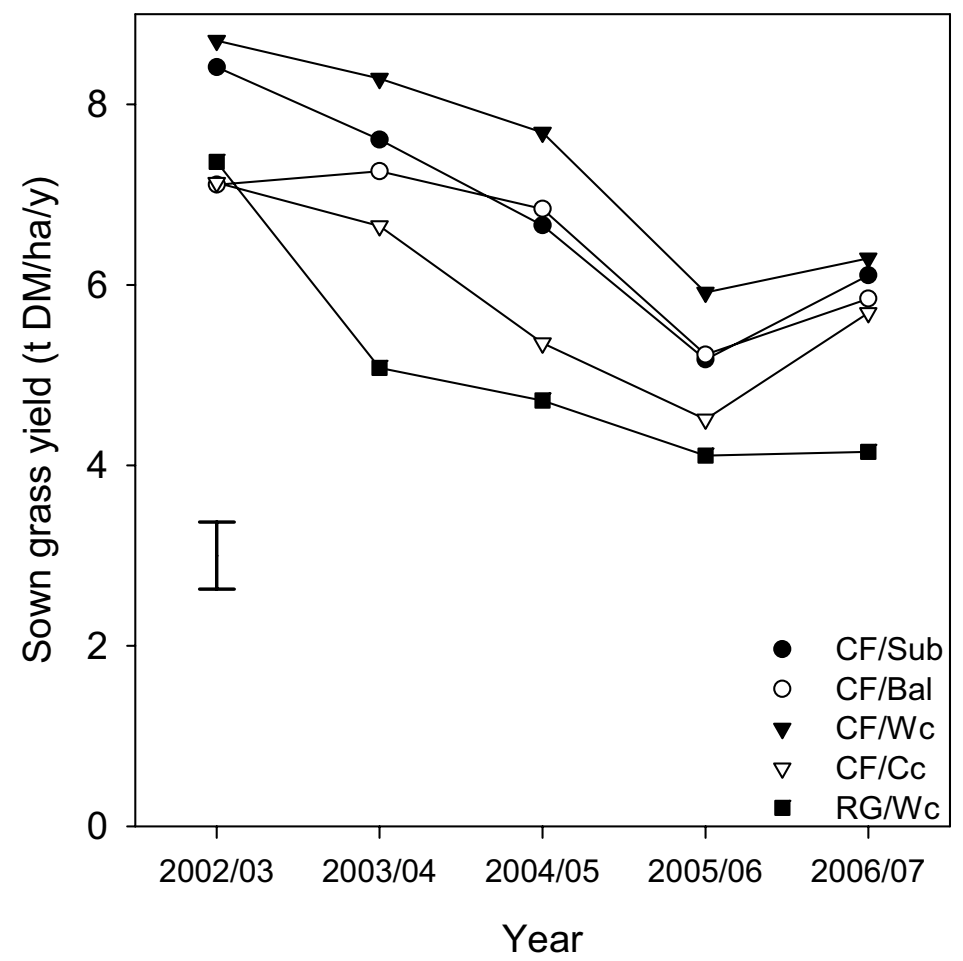

Figure 5 Total clover yields of dryland CF/Sub, CF/Bal, CF/Wc, CF/Cc and RG/Wc pastures, which includes volunteer white clover (VWC) contributions, over five growth seasons at Lincoln University, Canterbury, New Zealand. Error bars are SEM for total legume (sown + volunteer white clover) yields.
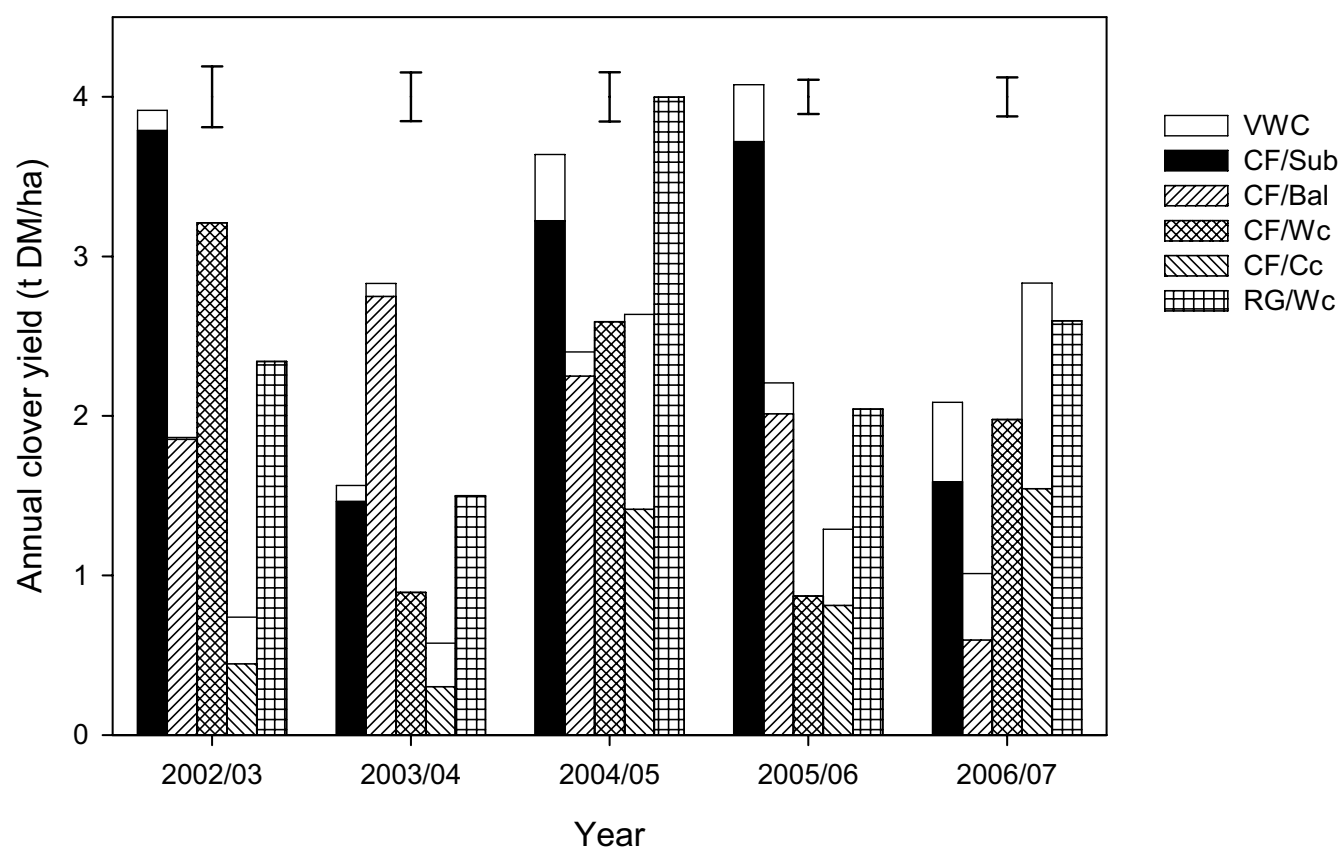
Figure 6 Yield of weed species in dryland CF/Sub, CF/Bal, CF/Wc, CF/Cc, RG/Wc and Luc pastures over five growth seasons at Lincoln University, Canterbury, New Zealand. The weed component of lucerne pastures includes volunteer white clover. Error bars are SEM.

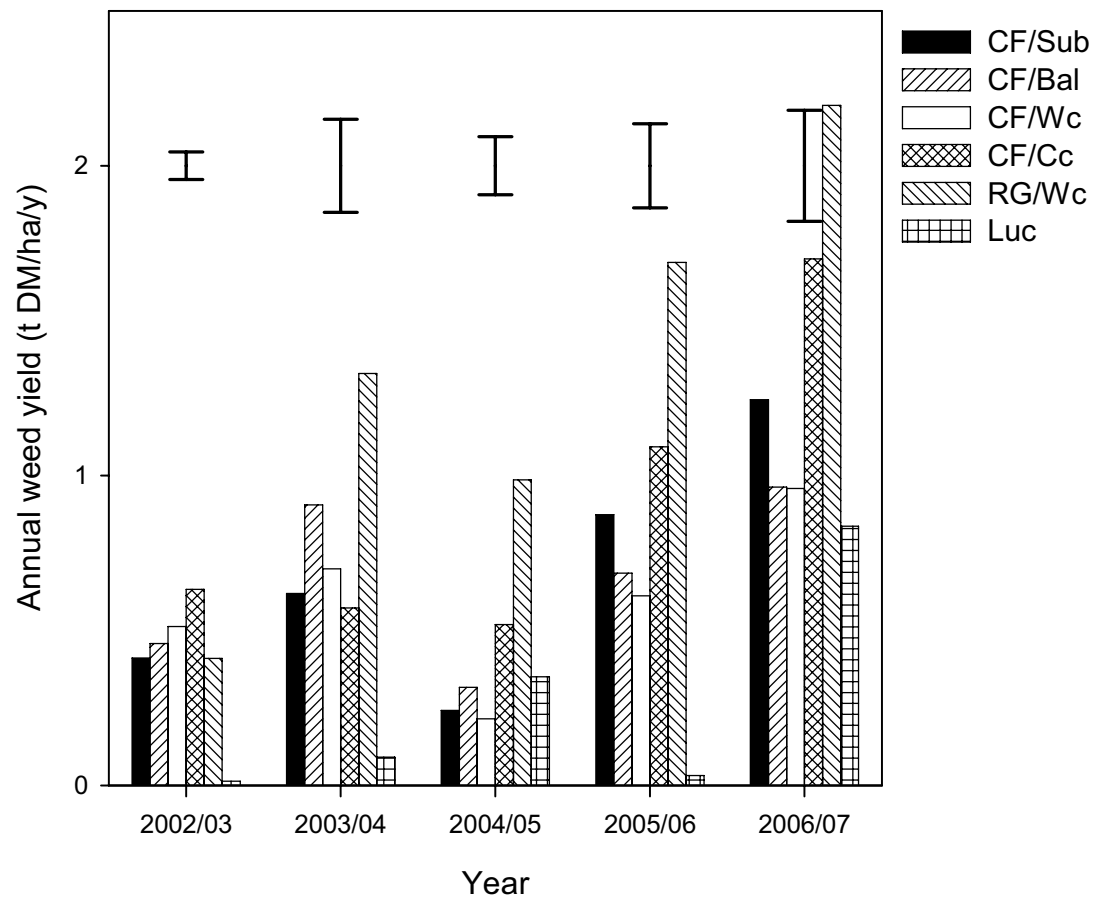

grass based pastures occurred in late spring from $\mathrm{CF} /$ Sub (95-107 kg DM/ha/d in November of Years 1-4). Pastures established with perennial legumes $(\mathrm{CF} / \mathrm{Wc}$, $\mathrm{CF} / \mathrm{Cc}$ and $\mathrm{RG} / \mathrm{Wc}$ ) had higher growth rates than annual legume based pastures in the wetter than average summers of 2004/05 and 2006/07. Early break rainfall increased autumn growth rates in all years before temperature limited winter production. Figure $3 \mathrm{~b}$ shows that, before water stress compromised spring growth, thermal time could be used to account for the seasonal temperature response using a base temperature of $3.0^{\circ} \mathrm{C}$ (Mills et al. 2006). The $\mathrm{CF} / \mathrm{Sub}$ grew at $8.3 \mathrm{~kg} \mathrm{DM} / \mathrm{ha} /{ }^{\circ} \mathrm{Cd}$ in spring when there was adequate water which was higher $(\mathrm{P}<0.05)$ than the $\mathrm{CF} / \mathrm{Wc}, \mathrm{CF} / \mathrm{Cc}$ and $\mathrm{RG} / \mathrm{Wc}$ pastures which grew at $6.5 \pm 0.48 \mathrm{~kg} \mathrm{DM} / \mathrm{ha} /{ }^{\circ} \mathrm{Cd}$. Regressions were not forced through the origin, and had a X-intercept of $133 \pm 10.0^{\circ} \mathrm{Cd}$ which indicates some systematic error in the calculation of thermal time which may be associated with the use of air temperature as the predictor (Jamieson et al. 1995).

\section{Sown grass yields}

Over time, the contribution of sown grass to total DM production declined (Fig. 4). This was most apparent in the $\mathrm{RG} / \mathrm{Wc}$ where grass yield decreased from $7.4 \mathrm{t} \mathrm{DM} /$ $\mathrm{ha} / \mathrm{yr}$ or $70 \%$ of the annual total in $2002 / 03$ to $\leq 4.7 \mathrm{t} / \mathrm{ha}$, or $\sim 45 \%$ of total annual DM production, in Years 3-5.
Cocksfoot yield also declined from $>7.0 \mathrm{t} \mathrm{DM} / \mathrm{ha}$ to a minimum of $4.5 \mathrm{t} \mathrm{DM} / \mathrm{ha} / \mathrm{yr}$ in the $\mathrm{CF} / \mathrm{Cc}$ pasture in 2005/06. In 2006/07, cocksfoot recovered to produce 5.7-6.3 t DM/ha/yr, or $53(\mathrm{CF} / \mathrm{Cc})$ to $70 \%(\mathrm{CF} / \mathrm{Bal})$ of total annual yield.

\section{Legume production}

As expected, the monocultures of lucerne produced the highest legume yield (9.5-17.3 t DM/ha/yr) and were excluded from this analysis. Of the sown clovers in the grass based pastures, clover content ranged from $4 \%$ $(\mathrm{CF} / \mathrm{Cc})$ to $40 \%(\mathrm{RG} / \mathrm{Wc})$ over the 5 years. In cocksfoot based pastures, subterranean clover yield was greater than, or similar to, sown clover yields in all other cocksfoot pastures in 4 of the 5 years (Fig. 5). The exception (2003/04) occurred from the first natural reseeding of annual clovers, when balansa clover yield was double that of subterranean clover. Subterranean clover produced the highest clover yields $(>3.7 \mathrm{t} \mathrm{DM} /$ ha/yr) in 2002/03 and 2005/06 and out-yielded the perennial legumes when summer rainfall was below the long-term average.

When summer rainfall was greater than, or equal to, the LTM (2004/05 and 2006/07), perennial white clover production was superior to the annual legumes. Specifically, white clover yield was $4.0 \mathrm{t} \mathrm{DM} / \mathrm{ha} / \mathrm{yr}$ in 2004/05 (RG/Wc) when summer (Dec-Feb) rainfall was 
$185 \mathrm{~mm}$, or $30 \%$ greater than the LTM. White clover in both the CF/Wc and RG/Wc pastures was $>1.9 \mathrm{t} \mathrm{DM} /$ $\mathrm{ha} / \mathrm{yr}$ in 2006/07 when summer rainfall (142 mm) was the same as the LTM. With the exception of 2002/03, white clover yields when sown with cocksfoot were 0.6-1.4 t DM/ha/yr lower than white clover sown with perennial ryegrass. Specifically, clover content of the $\mathrm{CF} / \mathrm{Wc}$ pastures was 9 to $23 \%$ compared with 18 to $40 \%$ in $\mathrm{RG} / \mathrm{Wc}$ pastures. Over time, Cc content increased from $\sim 5 \%$ (Years 1 and 2 ) to $10-16 \%$ in Years 3, 4 and 5 . Total clover content in the $\mathrm{CF} / \mathrm{Cc}$ pastures was almost doubled by the contribution of volunteer white clover in the wet summers of 2004/05 and 2006/07.

\section{Weed species}

In RG/Wc pastures the contribution of unsown species (yarrow (Achillea millefolium); dandelion (Taraxacum officinale); storksbill (Erodium cicutarium); hawksbeard (Crepis capillaris); Poa annua and barley grass (Hordeum murinum) ) increased from $4 \%$ of total annual $\mathrm{DM}$ yield in $2002 / 03$ to $23 \%$, or $2.2 \mathrm{t} \mathrm{DM} / \mathrm{ha} / \mathrm{yr}$, by 2006/07 (Fig. 6). Weed content of pastures was unaffected by treatment in Year $2(0.7 \pm 0.30 \mathrm{t} \mathrm{DM} / \mathrm{ha} / \mathrm{yr})$. However, in $2004 / 05$ and $2006 / 07$, trends $(\mathrm{P}<0.1$, not shown) indicated weed yield in $\mathrm{RG} / \mathrm{Wc}$ pastures was greater than all other pastures. The weed yield from lucerne has been $\leqslant 5 \%$ of total DM production in all 5 years, but it has received winter herbicide (paraquat and atrazine) applications of $1.5 \mathrm{~L} / \mathrm{ha}$ Atrazine 90DF (a.i. $900 \mathrm{~g} / \mathrm{kg}$ atrazine) and $1 \mathrm{~L} /$ ha Gramoxone (a.i. $250 \mathrm{~g} / \mathrm{L}$ paraquat) in 2005 and 2007.

\section{Discussion}

The superiority of lucerne yields in 4 of the 5 years (Fig. 2) was achieved through higher summer growth rates than grass based pastures (Fig. 3). Lucerne was also the most responsive species to summer rainfall and, in the wetter 2004/05 and 2006/07 years, out-yielded the next highest grass based pasture by $>6.6 \mathrm{t} \mathrm{DM} / \mathrm{ha} / \mathrm{yr}$. The exception was in $2005 / 06$ when winter rainfall was $74 \%$ below average and snow (August 2005) flattened young lucerne shoots and caused slow canopy regeneration followed by low spring $(-14 \%)$ and summer $(-25 \%)$ rainfall (Fig. $1 b)$. It is likely that winter rainfall was insufficient to recharge soil moisture at depth and consequently lucerne only had summer/autumn growth rates comparable to grass based pastures (Fig. 3). In 2006/07, lucerne crops recovered their yield superiority.

Lucerne requires rotational grazing (Moot et al. 2003) and therefore other pastures are required to provide early season production to meet stock demand during lambing and early lactation. The most consistent spring pasture combination was $\mathrm{CF} / \mathrm{Sub}$ with yields (Fig. 2) greater than, or similar to, pastures established with perennial white clover in most years. In spring, $\mathrm{CF} / \mathrm{Sub}$ pastures generally produced $>90 \mathrm{~kg} \mathrm{DM} / \mathrm{ha} / \mathrm{d}$ (Fig. 3) which highlights their superiority over RG/Wc pastures at this time.

When spring production was summarised against thermal time (Fig. 3b), CF/Sub pastures produced DM at a near constant rate of $8.3 \mathrm{~kg} \mathrm{DM} / \mathrm{ha} /{ }^{\circ} \mathrm{Cd}$ above a base air temperature of $3^{\circ} \mathrm{C}$ compared with $\mathrm{CF} / \mathrm{Wc}, \mathrm{CF} / \mathrm{Cc}$ and $\mathrm{RG} / \mathrm{Wc}$ pastures which produced about $2 \mathrm{~kg} \mathrm{DM} /$ ha $/{ }^{\circ} \mathrm{Cd}$ less. Pastures sown with annual legumes produced DM more rapidly, per thermal unit, than reported previously for a cocksfoot monoculture grown with non limiting $\mathrm{N}$ fertiliser (Mills et al. 2006). Perennial legume based pastures produced $>2.4 \mathrm{~kg} \mathrm{DM} / \mathrm{ha} /{ }^{\circ} \mathrm{Cd}$ than $\mathrm{N}$ deficient cocksfoot monocultures (Mills et al. 2006). Therefore, in October which has a LTM monthly air temperature of $11.4^{\circ} \mathrm{C}$ (Fig. 1a), the $\mathrm{CF} / \mathrm{Sub}$ pastures could be expected to produce $70 \mathrm{~kg} \mathrm{DM} / \mathrm{ha} / \mathrm{d}$ or $\sim 15 \mathrm{~kg} /$ $\mathrm{DM} / \mathrm{ha} / \mathrm{d}$ more than pastures which included perennial legumes. In years with moist summers, pastures established with perennial clovers responded to additional rainfall but production from subterranean clover peaked in mid to late spring before it set seed.

Caucasian clover yield was $<0.5 \mathrm{t} \mathrm{DM} / \mathrm{ha} / \mathrm{yr}$ or $4-5 \%$ of total DM yield in the first 2 years (Fig. 5) and this reflects the less than ideal conditions for its establishment (Black et al. 2006). In Years 3 and 5, when summer rainfall was average to above average, Cc yields were $>1.4 \mathrm{t} \mathrm{DM} / \mathrm{ha} / \mathrm{yr}$ and represented $14-16 \%$ of total annual production. This was enhanced by DM production from volunteer white clover which increased total clover content to $39 \%$ in both years. This highlights the complementarity of these two species (Black \& Lucas 2000) and the increase in Cc content with time (Lucas et al. 1981).

After the establishment year, white clover yields from $\mathrm{CF} / \mathrm{Wc}$ pastures were 0.6-1.4 t DM/ha/yr less than white clover in RG/Wc pastures. Cocksfoot is slower to establish than perennial ryegrass because it needs to accumulate about $75 \%$ more thermal time for $50 \%$ field emergence (Moot et al. 2000). This reduces its competitive ability and allows other slower establishing species, such as white clover, a chance to establish. The current work shows that clover establishment is improved if perennial ryegrass is excluded from dryland pasture mixes. Previous work has shown that cocksfoot pastures typically show a reduction in white clover content over time (Lee \& Cho 1985).

Ingress of unsown annual grasses may, on completion of their lifecycle, increase the proportion of bare ground where seedlings of more invasive perennial dicotyledonous weeds establish. Production by perennial ryegrass declined by $\sim 0.7 \mathrm{t} / \mathrm{ha} / \mathrm{yr}$ (Fig. 4 ) and the contribution of unsown species increased from $0.4 \mathrm{t} \mathrm{DM} /$ ha/yr in $2002 / 03$ to $2.2 \mathrm{t} \mathrm{DM/ha/yr} \mathrm{by} 2006 / 07$ (Fig 6). 
These results suggest $\mathrm{Rg} / \mathrm{Wc}$ pastures would need to be resown before any of the CF based pastures. This supports previous work which showed poor production and a lack of persistence of RG/Wc pastures in dryland systems (Woodman et al. 1992; Knowles et al. 2003).

The reduction in clover yield from $\mathrm{CF} / \mathrm{Bal}$ pastures appears to have been caused by inadequate reseeding and false breaks. This is discussed in detail by Monks et al. (2008). Overall the current results suggest a combination of subterranean and white clovers in cocksfoot based pastures, without perennial ryegrass, as a suitable pasture capable of responding to the environmental variability in dryland conditions. Subterranean clover was the most productive companion legume for cocksfoot for spring production, while white clover (sown or volunteer) successfully responded to summer rainfall. Successful subterranean clover management in these cocksfoot pastures has included hard grazing prior to the first autumn rains. This allows light to the establishing annual legume seedlings so they are not out-competed by cocksfoot.

\section{Conclusions}

- Lucerne produced the highest yields of 13.1-18.5 t $\mathrm{DM} / \mathrm{ha} / \mathrm{yr}$ in 4 out of 5 years.

- Cocksfoot pastures sown with subterranean and white clover complement lucerne production in summer dry environments with unpredictable summer rainfall.

- Production from $\mathrm{CF} / \mathrm{Sub}$ pastures was highest in spring and $\mathrm{CF} / \mathrm{Wc}$ pastures provided feed in moist summers.

- By Year 5, ryegrass represented $44 \%$ of total annual DM yield while unsown grasses and dicotyledonous weeds contributed $24 \%$, white clover was $27 \%$ and dead material was $5 \%$ of annual yield in $\mathrm{RG} / \mathrm{Wc}$ pastures.

\section{ACKNOWLEDGEMENTS}

A. Mills acknowledges financial assistance from Meat \& Wool NZ through the FoRST Pastoral21 programme, Lincoln University and the Cocksfoot Growers Association.

\section{REFERENCES}

Black, A.D.; Lucas, R.J. 2000. Caucasian clover was more productive than white clover in grass mixtures under drought conditions. Proceedings of the New Zealand Grassland Association 62: 183-188.

Black, A.D.; Moot, D.J.; Lucas, R.J. 2006. Spring and autumn establishment of Caucasian and white clovers with different sowing rates of perennial ryegrass. Grass and Forage Science 61: 430-441.

Brown, H.E.; Moot, D.J.; Lucas, R.J.; Smith, M. 2006. Sub clover, cocksfoot and lucerne combine to improve dryland stock production. Proceedings of the New Zealand Grassland Association 68: 109-115.

Edwards, G.R.; Lucas, R.J.; Johnston, M.R. 1993. Grazing preference for pasture species by sheep is affected by endophyte and nitrogen fertility. Proceedings of the New Zealand Grassland Association 55: 137-141.

Jamieson, P.D.; Brooking, I.R.; Porter, J.R.; Wilson, D.R. 1995. Prediction of leaf appearance in wheat: a question of temperature. Field Crops Research 41:35-44.

Knowles, I.M.; Fraser, T.J.; Daly, M.J. 2003. White clover: loss in drought and subsequent recovery. Legumes for Dryland Pastures. Grassland Research and Practice Series 11: 37-41.

Lee, H.J.; Cho, M.J. 1985. Root competition and productivity in mono- and binary association of four forage species. pp. 663-665. In: Proceedings of the XV International Grassland Congress, August 24-31, Kyoto, Japan.

Lucas, R.J.; White, J.G.H.; Daly, G.T.; Jarvis, P.; Meijer, G. 1981. Lotus, white clover and Caucasian clover oversowing, Mesopotamia Station, South Canterbury. Proceedings of the New Zealand Grassland Association 42: 142-151.

Mills, A.; Moot, D.J.; McKenzie, B.A. 2006. Cocksfoot pasture production in relation to environmental variables. Proceedings of the New Zealand Grassland Association 68: 89-94.

Mills, A.; Smith, M.C.; Moot, D.J. 2008. Liveweight production from dryland lucerne, cocksfoot or ryegrass based pastures. In press In: Global Issues, Paddock Action. Proceedings of the 14th ASA Conference, 2125 September 2008, Adelaide, South Australia

Monks, D.P.; Moot, D.J.; Smith, M.C.; Lucas, R.J. 2008. 'Bolta' balansa clover persistence in a grazed cocksfoot pasture depended on spring and summer grazing management. Proceedings of the New Zealand Grassland Association 70: 233-238.

Moot, D.J.; Scott, W.R.; Roy, A.M.; Nicholls, A.C. 2000. Base temperature and thermal time requirements for germination and emergence of temperate pasture species. New Zealand Journal of Agricultural Research 43: 1525.

Moot, D.J.; Brown, H.E.; Teixeira, E.I.; Pollock, K.M. 2003. Crop growth and development affect seasonal priorities for lucerne management. Legumes for Dryland Pastures. Grassland Research and Practice Series 11: 201-208.

Norris, I.B. 1982. Soil moisture and growth of contrasting varieties of Lolium, Dactylis and Festuca species. Grass and Forage Science 37: 273-283.

Woodman, R.F.; Keoghan, J.M.; Allan, B.E. 1992. Pasture species for the drought-prone lower slopes in the South Island high country. Proceedings of the New Zealand Grassland Association 54: 115-120. 